\title{
Flos magnoliae constituent fargesin has an anti-allergic effect via ORAI1 channel inhibition
}

\author{
Phan Thi Lam Hong ${ }^{1,2, *}$, Hyun Jong Kim ${ }^{2, *}$, Woo Kyung Kim ${ }^{2,3, *}$, and Joo Hyun Nam ${ }^{1,2, *}$ \\ ${ }^{1}$ Department of Physiology, Dongguk University College of Medicine, Gyeongju 38066, ${ }^{2}$ Channelopathy Research Center (CRC), Dongguk University College of \\ Medicine, Goyang 10326, ${ }^{3}$ Department of Internal Medicine, Graduate School of Medicine, Dongguk University, Goyang 10326, Korea
}

\section{ARTICLE INFO}

Received February 25, 2021

Revised March 5, 2021

Accepted March 9, 2021

*Correspondence

Joo Hyun Nam

E-mail: jhnam@dongguk.ac.kr

Woo Kyung Kim

E-mail:wk2kim@naver.com

\section{Key Words}

Eudesmin

Fargesin

Mast cell

ORAI

T Lymphocyte

\#These authors contributed equally to this work.

\begin{abstract}
Flos magnoliae (FM), the dry flower buds of Magnolia officinalis or its related species, is a traditional herbal medicine commonly used in Asia for symptomatic relief of and treating allergic rhinitis, headache, and sinusitis. Although several studies have reported the effects of FM on store-operated calcium entry (SOCE) via the ORAI1 channel, which is essential during intracellular calcium signaling cascade generation for $T$ cell activation and mast cell degranulation, the effects of its isolated constituents on SOCE remain unidentified. Therefore, we investigated which of the five major constituents of $30 \%$ ethanoic FM (vanillic acid, tiliroside, eudesmin, magnolin, and fargesin) inhibit SOCE and their physiological effects on immune cells. The conventional whole-cell patch clamp results showed that fargesin, magnolin, and eudesmin significantly inhibited SOCE and thus human primary CD4 ${ }^{+} \mathrm{T}$ lymphocyte proliferation, as well as allergen-induced histamine release in mast cells. Among them, fargesin demonstrated the most potent inhibitory effects not only on ORAI 1 $\left(\mathrm{IC}_{50}=12.46 \pm 1.300 \mu \mathrm{M}\right.$ ) but also on T-cell proliferation (by $87.74 \% \pm 1.835 \%$ ) and mast cell degranulation (by $20.11 \% \pm 5.366 \%$ ) at $100 \mu \mathrm{M}$. Our findings suggest that fargesin can be a promising candidate for the development of therapeutic drugs to treat allergic diseases.
\end{abstract}

\section{INTRODUCTION}

Allergies, caused by immune responses to environmental antigens are some of the most common chronic inflammatory diseases worldwide. The responses lead to the release of Th-2 T cells that produce interleukin (IL)-4, IL-5, and IL-13 and boost IgE-mediated activation and degranulation of mast cells [1]. In general, allergies result from exposure to several common allergens such as pollen, animal dander, house dust mites, specific food, insect venom, and several drugs. They are commonly recognized as type I hypersensitivities that exhibit the most clear-cut immunopathological correlation and are referred to as IgE-mediated allergic reactions [2]. Allergic reactions generally include two distinct phases, the early-phase reaction and the late- phase response. The early-phase reaction is activated within a few minutes of exposure to allergens; it generates mediators such as histamine, prostaglandins, and leukotrienes from mast cells that initiate a series of events, namely increased vascular permeability with edema, itchiness, vasodilation, and several acute functional changes in the related organs $[3,4]$. As a result, leukocytes that are increasingly recruited and activated during hypersensitivity augment the late-phase response that develops more slowly than the early-phase reaction and reflects the accumulation of Th2 T cells, basophils, eosinophils, leukocytes, and mediators generated by resident cells such as mast cells $[3,5,6]$. The maintenance of specific allergen exposure or repetitive exposure can trigger a state of chronic allergic inflammation $[3,5]$.

Intracellular calcium signaling is activated and modulated dur-

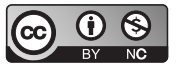

This is an Open Access article distributed under the terms of the Creative Commons Attribution Non-Commercial License, which permits unrestricted non-commercial use, distribution, and reproduction in any medium, provided the original work is properly cited. Copyright @ Korean J Physiol Pharmacol, pISSN 1226-4512, elSSN 2093-3827
Author contributions: J.H.N. conceived and supervised the study; H.J.K. designed the experiments; H.J.K. and P.T.L.H. performed experiments and analyzed data; P.T.L.H., H.J.K., W.K.K., and J.H.N. discussed the results and commented on the manuscript; P.T.L.H. wrote the manuscript in consultation with J.H.N. 
ing the allergic response phases. Calcium is one of the essential second messengers in several cell types, especially immune cells such as B and T lymphocytes that regulate cytokine secretion, cell differentiation, and the non-reactive state $[7,8]$. The intracellular calcium concentration of immunocytes in the resting state is $~ 100 \mathrm{nM}$. However, it is transiently increased when T or B cell immunocyte surface receptors or antigen-antibody complexes engage with Fc receptors in mast cells, leading to intracellular calcium signaling through the Gq protein-coupled receptor [9-12]. Consequent to receptor activation, phospholipase $\gamma$ is stimulated and cleaves phosphatidylinositol 4,5-bisphosphate into inositol 1,4,5-trisphosphate $\left(\mathrm{IP}_{3}\right)$ and diacylglycerol (DAG). Whereas DAG remains in the plasma membrane, $\mathrm{IP}_{3}$ moves and binds to $\mathrm{IP}_{3}$ receptors on the endoplasmic reticulum (ER), followed by the release of calcium from the ER stores into the cytoplasm, generating transient calcium signaling $[9,13,14]$. To foster the continuation of cellular reactions, a different mechanism, termed storeoperated calcium entry (SOCE), is activated. SOCE is a calciumselective calcium release-activated calcium (CRAC) channel, mediated by the interaction among stromal interaction molecule 1 (STIM1), ER calcium sensor, and the ORAI1 plasma membrane calcium channel. The CRAC channel is responsible for the function and differentiation of some $\mathrm{T}$ lymphocyte subsets, contributing immunity to infection, inflammation, and the prevention of autoimmune diseases [15].

ORAIl is abundantly expressed and plays a vital role in activating immune cells, such as $\mathrm{T}$ and mast cells. Loss-of-function changes in ORAI1 or its activator STIM1 inhibit CRAC currents and SOCE [10,16-18]. A previous report has illustrated the important role of ORAIl in allergic skin disorders [19], and more recently, DS-2741a, an anti-ORAIl antibody, has been shown to suppress $\mathrm{T}$ cell and mast cell functions [20]. In addition, although allergic responses can now be effectively medicated, there are still misgivings concerning the adverse side effects of antiallergic drugs and the associated increased medical expenses. These factors indicate the importance of developing functional natural products targeting ORAIl, to reduce or prevent allergies.

Flos magnoliae (FM), the dry flower buds of Magnolia officinalis or its related species, is a traditional herbal medicine commonly used in Asia for symptomatic relief of and treating allergic rhinitis, headache, and sinusitis [21-23]. FM extracts and compounds have been reported to exhibit significant antiallergic and anti-inflammatory effects by inhibiting mast cell degranulation and pro-inflammatory cytokine secretion. The primary constituents of a $30 \%$ ethanolic FM extract $\left(\mathrm{FM}_{\mathrm{EtOH}}\right)$ have been previously determined as vanillic acid, tiliroside, eudesmin, magnolin, and fargesin [21]. In addition, several studies have reported the FM immunosuppressive mechanism with respect to the ORAI1 channel intracellular calcium signal [6,22-25]. Nevertheless, its constituent effects on SOCE regulation and physiological effects in the immune cells involved in allergic diseases are still unknown. Thus, this study aimed to assess the effects of five major
FM constituents on SOCE. Among them, we identified three FM compounds that significantly inhibit SOCE and its related physiological effects, namely fargesin, eudesmin, and magnolin, which could be promising therapeutic agents for allergic diseases.

\section{METHODS}

\section{Cell culture}

Human embryonic kidney 293 T (HEK293T), RBL-2H3 mast cells, and Jurkat $\mathrm{T}$ cells were obtained from the American Type Culture Collection (Manassas, VA, USA). HEK293T cells were maintained at $37^{\circ} \mathrm{C}$ with $10 \% \mathrm{CO}_{2}$ in Dulbecco's modified Eagle's medium (Welgene, Gyeongsan, Korea) supplemented with 10\% fetal bovine serum (FBS; Welgene) and 1\% penicillin/streptomycin (P/S; GE Healthcare, Chicago, IL, USA). RBL-2H3 cells were cultured in minimum essential medium (Gibco, Grand Island, NY, USA), whereas Jurkat $\mathrm{T}$ cells were grown in RPMI1640 medium (Gibco; Thermo Fisher Scientific, Waltham, MA, USA) supplemented with $10 \% \mathrm{FBS}$ and $1 \% \mathrm{P} / \mathrm{S}$; both cell lines were maintained at $37^{\circ} \mathrm{C}$ in a $5 \% \mathrm{CO}_{2}$ incubator.

\section{hSTIM1 and hORAI1 transfection}

HEK293T cells were transfected using TurboFect transfection reagent (Thermo Scientific, Waltham, MA, USA) to record the ORAIl current, following the manufacturer's instructions. The human ORAI1 (hORAI1), human STIM1 (hSTIM1), and enhanced green fluorescence protein-encoding construct (pEGFP$\mathrm{N1}$ ) vectors were transiently co-transfected in a 4.5:4.5:1 ratio. The electrophysiological experiments were performed $24 \mathrm{~h}$ after co-transfection.

\section{$\mathrm{FM}_{\mathrm{EtOH}}$ preparation}

Twenty grams of the dried FM obtained from SAEROM Pharmaceutical Co. Ltd. (Anseong, Korea) was thoroughly pulverized and reflux-extracted with $30 \%$ ethanol. The resultant $\mathrm{FM}_{\mathrm{EtOH}}$ was concentrated using a rotary vacuum evaporator. The $16.8 \%$ yield was freeze-dried and then stored at $25^{\circ} \mathrm{C}$.

\section{$\mathrm{FM}_{\mathrm{EtOH}}$ constituent analysis}

A 1290 Series high-performance liquid chromatograph (Agilent Technologies, Santa Clara, CA, USA) at The Korea Basic Science Institute, Seoul, Republic of Korea, was used to analyze the $\mathrm{FM}_{\mathrm{EtOH}}$ constituents as previously described [26]. After injecting $10 \mu \mathrm{l}$ of $5 \mathrm{mg} / \mathrm{ml} \mathrm{FM}_{\mathrm{EtOH}}$ into a $3.0 \times 100 \mathrm{mM}, 2.7 \mu \mathrm{M}$ Poroshell 120 SB-C18 column (Agilent Technologies), the constituents were separated and identified at a $278 \mathrm{nM}$ wavelength. The column temperature was maintained at $20^{\circ} \mathrm{C}$. In addition, the mobile 
phases, including $0.1 \%$ acetic acid (A) and acetonitrile (B) solutions, were used with 10\%-65\% B (15 min), 65\%-90\% B (1 min), and $90 \% \mathrm{~B}(2 \mathrm{~min})$ and were equilibrated with $10 \% \mathrm{~B}$.

\section{$\beta$-Hexosaminidase activity assay}

The $\beta$-hexosaminidase activity was determined by colorimetric assay using p-nitrophenyl $\mathrm{N}$-acetyl-D-glucosamine hydrolysis, as previously described [26,27]. RBL-2H3 mast cells were seeded in 48-well plates $\left(2.5 \times 10^{5}\right.$ cells $\left./ \mathrm{ml}\right)$ and incubated for 24 $\mathrm{h}$ before sensitization with $1.0 \mathrm{mg} / \mathrm{ml}$ anti-dinitrophenyl (DNP)IgE for $3 \mathrm{~h}$ followed by discarding the solution and washing the cells four times with PBS. Subsequently, the stimulated cells were exposed to $3,10,30$, and $100 \mu \mathrm{M}$ of fargesin or eudesmin before dissolution in piperazine-N, N0-bis(2-ethanesulfonic acid) buffer containing $119 \mathrm{mM} \mathrm{NaCl}, 5 \mathrm{mM} \mathrm{KCl}, 25 \mathrm{mM}$ PIPES, $5.6 \mathrm{mM}$ glucose, $1 \mathrm{mM} \mathrm{CaCl}, 0.4 \mathrm{mM} \mathrm{MgCl}_{2}$, and $0.1 \%$ bovine serum albumin ( $\mathrm{pH} 7.2, \mathrm{NaOH}$ ), and stimulation with $800 \mathrm{ng} / \mathrm{ml}$ DNPhorse serum albumin for $1.5 \mathrm{~h}$. The cells were subsequently incubated for $1.5 \mathrm{~h}$ at $37^{\circ} \mathrm{C}$ in a medium mixture of $1 \mathrm{mM} \mathrm{p}-$ nitrophenyl $N$-acetyl-D-glucosamine and citrate buffer ( $\mathrm{pH} 4.5$ ). Sodium carbonate buffer ( $\mathrm{pH}$ 10.0) was added to the mixture to stop the reaction, and the absorbance at $405 \mathrm{nM}$ was immediately measured.

\section{Electrophysiology}

We performed the whole-cell patch clamp current recordings using an Axopatch 200B amplifier (Molecular Devices, Sunnyvale, CA, USA) and a Digidata 1440A interface (Molecular Devices) to measure the ORAIl current, as described in previous studies [21,22,26-29]. In brief, the transfected cells were transferred to a perfusion bath chamber (Warner Instruments, Hamden, CT, USA) and incubated for 5-10 min. The recorded current was sampled at $10 \mathrm{kHz}$, whereas the lowpass was filtered at 5 $\mathrm{kHz}$. The patch pipettes were pulled using a P97 flaming brown micropipette puller (Narishige, East Meadow, NY, USA) and polished to 2-3 MOhm. After setting up the standard whole-cell configuration, the voltage protocol was established by applying voltage ramps from $-130 \mathrm{mV}$ to $+70 \mathrm{mV}$ for $100 \mathrm{sec}$ at a holding potential of $-10 \mathrm{mV}$. The pulse was applied every $20 \mathrm{sec}$. The electrophysiological data were analyzed using Clampfit 10.4 (Molecular Devices, San Jose, CA, USA), Origin 8.0 software (Microcal, Northampton, MA, USA), and Prism 6.0 (GraphPad Software, La Jolla, CA, USA).

The bath solution composition was $135 \mathrm{mM} \mathrm{NaCl}, 3.6 \mathrm{mM}$ $\mathrm{KCl}, 1 \mathrm{mM} \mathrm{MgCl}, 10 \mathrm{mM} \mathrm{CaCl}_{2}, 5 \mathrm{mM}$ D-glucose, and $10 \mathrm{mM}$ HEPES ( $\mathrm{pH} 7.4, \mathrm{NaOH}$ ). The internal solution contained $130 \mathrm{mM}$ Cs-glutamate, $20 \mathrm{mM}$ BAPTA, $1 \mathrm{mM} \mathrm{MgCl}, 3 \mathrm{mM} \mathrm{MgATP}$, $0.002 \mathrm{mM}$ sodium pyruvate, and $20 \mathrm{mM}$ HEPES (pH 7.2, CsOH). Further, $20 \mu \mathrm{M}$ of $\mathrm{IP}_{3}$, which can deplete ER $\mathrm{Ca}^{2+}$ stores, was added to the pipette solution before experimentation to activate the ORAIl current. When the $\mathrm{I}_{\mathrm{SOCE}}$ reached a steady-state, we serially added $100 \mu \mathrm{M}$ of the FM constituents or the indicated concentrations of fargesin to the bath solution. At the end of each experiment, we also confirmed the basal current using BTP2, a potent ORAIl channel inhibitor.

\section{Human primary $\mathrm{CD}^{+} \mathrm{T}$ lymphocyte isolation}

The experimental procedures using human blood were authorized by the Institutional Review Board (IRB), Dongguk University College of Medicine, Korea (IRB No. 2017-07-003). The peripheral blood mononuclear cells were isolated using the Ficoll-Paque Plus medium (GE Healthcare, Chicago, IL, USA), followed by the isolation of human naive $\mathrm{T}$ lymphocytes using a CD4 ${ }^{+} \mathrm{T}$ cell isolation kit (Miltenyi Biotec, Bergisch Gladbach, Germany), according to the manufacturer's protocol and a previous study [27].

\section{T cell proliferation assay}

T cells were purified and washed twice with PBS before suspension in PBS at a $10^{5}-10^{6}$ cells/ml followed by the addition of carboxyfluorescein succinimidyl ester (CFSE; Thermo Fisher Scientific) and maintained at room temperature for $10 \mathrm{~min}$. Cold media were added to stop the reaction, and the cells were placed on ice for $5 \mathrm{~min}$. The CFSE-labeled cells were seeded in 96-well plates at $2 \times 10^{5}$ cells/well, and simultaneously stimulated with 5 $\mu \mathrm{l} / \mathrm{ml}$ antihuman CD3 and $2 \mu \mathrm{l} / \mathrm{ml}$ antihuman CD28 (Thermo Fisher Scientific). Subsequently, the $\mathrm{CD} 4^{+} \mathrm{T}$ cell proliferation was determined by fluorescence-activated cell sorting after incubation with complete RPMI-1640 media for 3 days, according to a previous study [27].

\section{Cytotoxicity assay}

Cell viability was determined using a cell counting Kit-8 (CCK8; Dojindo Laboratories, Kumamoto, Japan). Specifically, Jurkat T cells were plated in 96-well plates at $2 \times 10^{4}$ cells per well, treated with $1,3,10,30$, and $100 \mu \mathrm{M}$ fargesin, eudesmin, or magnolin and incubated for $72 \mathrm{~h}$. Subsequently, $10 \mu \mathrm{l}$ of CCK- 8 solution was added to each well of the cultured cells and incubated for an additional $3 \mathrm{~h}$, followed by the absorbance measurement at $450 \mathrm{~nm}$ using a microplate reader.

\section{Statistical analyses}

The experimental results are expressed as the means \pm standard error of the means (SEM). The statistical analyses were performed using one-way ANOVA with Bonferroni and HolmSidak post-hoc tests for multiple comparisons. The $\mathrm{p}<0.05$ was considered statistically significant. 


\section{RESULTS}

\section{Inhibition of $\mathrm{I}_{\text {SOCE }}$ by $\mathrm{FM}_{\mathrm{EtOH}}$ constituents in hORAI1} and hSTIM1 co-transfected HEK293T cells

Five constituent compounds (eudesmin, fargesin, magnolin, tiliroside, and vanillic acid) were identified in the $30 \%$ ethanoic FM in our previous study [21]. To determine whether these five compounds show the inhibitory effects on the ORAI1 current $\left(\mathrm{I}_{\text {ORAII }}\right)$, we performed whole-cell patch clamp on the HEK293T cells that co-expressed hORAI1 and hSTIM1. The addition of 20 $\mathrm{mM}$ 1,2-bis(o-aminophenoxy)ethane-N,N,N0, N0-tetraacetic acid (BAPTA) and $20 \mu \mathrm{M} \mathrm{IP}_{3}$ to the intracellular solution developed $\mathrm{I}_{\text {ORAII }}$ (Fig. 1A). After the $\mathrm{I}_{\mathrm{ORAI}}$ attained peak value, $100 \mu \mathrm{M}$ of each of the constituents was added separately. Interestingly, whereas vanillic acid and tiliroside did not exhibit significant effects, the three other compounds, fargesin, magnolin, and eudesmin, significantly inhibited $\mathrm{I}_{\text {ORAII }}$ by $65.58 \% \pm 8.384 \%, 29.73 \%$ $\pm 4.879 \%$, and $24.69 \% \pm 3.986 \%$, respectively (Fig. 1B). Since fargesin showed the most significant inhibitory effect on $\mathrm{I}_{\text {ORAII }}$, we applied it to $\mathrm{HEK}_{\mathrm{ORAI1}}$ cells at various concentrations (Fig. 2A, B). Fig. 2C shows that fargesin exhibited dose-dependent inhibition with an $\mathrm{IC}_{50}$ value of $12.46 \pm 1.300 \mu \mathrm{M}$.

\section{Inhibition of mast cell degranulation}

The SOCE plays a crucial functional role in degranulation and secretion in mast cells $[15,30]$. As recently published data has shown that magnolin inhibits IgE-antigen (Ag)-induced mast cell degranulation in a dose-dependent manner, we examined

A

Magnolin

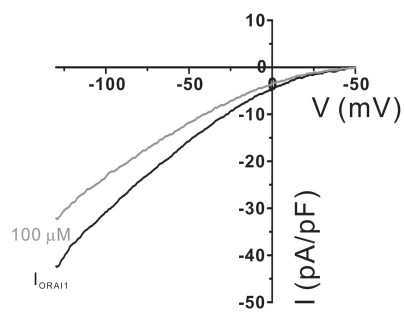

Tiliroside

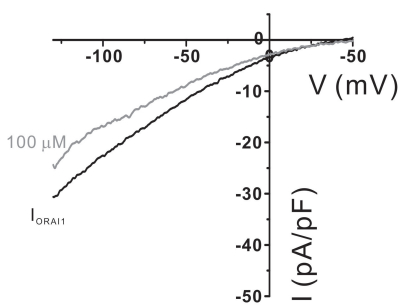

Fargesin

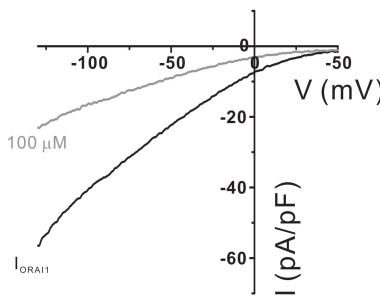

Vanillic acid

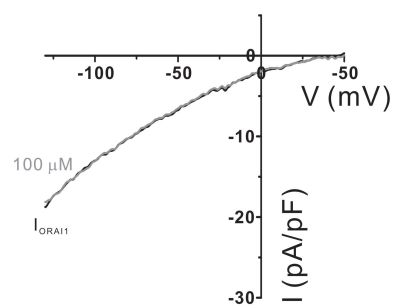

\section{Eudesmin}

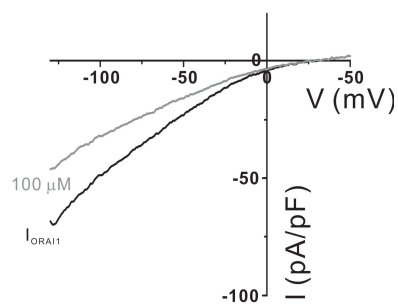

B

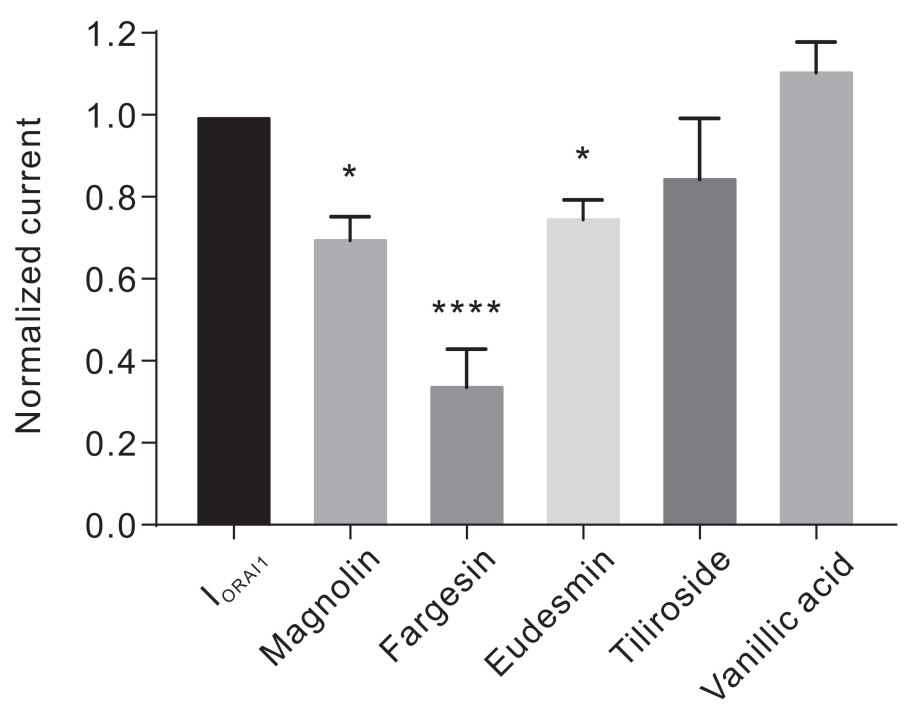

Fig. 1. Inhibitory effects of five major constituent chemical compounds in $30 \%$ Flos magnoliae ethanolic extract $\left(\mathrm{FM}_{\mathrm{EtOH}}\right)$ on the ORAl1 current $\left(\mathrm{I}_{\mathrm{ORAI1}}\right)$ in HEK293T cells co-expressing ORAI1 and stromal interaction molecule 1 (STIM1). (A) Representative current (I)voltage $(\mathrm{V})$ relationship curve showing $\mathrm{I}_{\text {ORAI1 }}$ by various constituents $(100 \mu \mathrm{M})$ and BTP2. (B) Normalized I IRA11 inhibition histograms indicating treatment with various constituents $(100 \mu \mathrm{M})$ at -120 $\mathrm{mV}$. Values are presented as mean \pm SEM. ${ }^{*} \mathrm{p}<0.05$ and ${ }^{* * * *} \mathrm{p}<0.0001 \mathrm{com}-$ pared to control (I IRAII). 

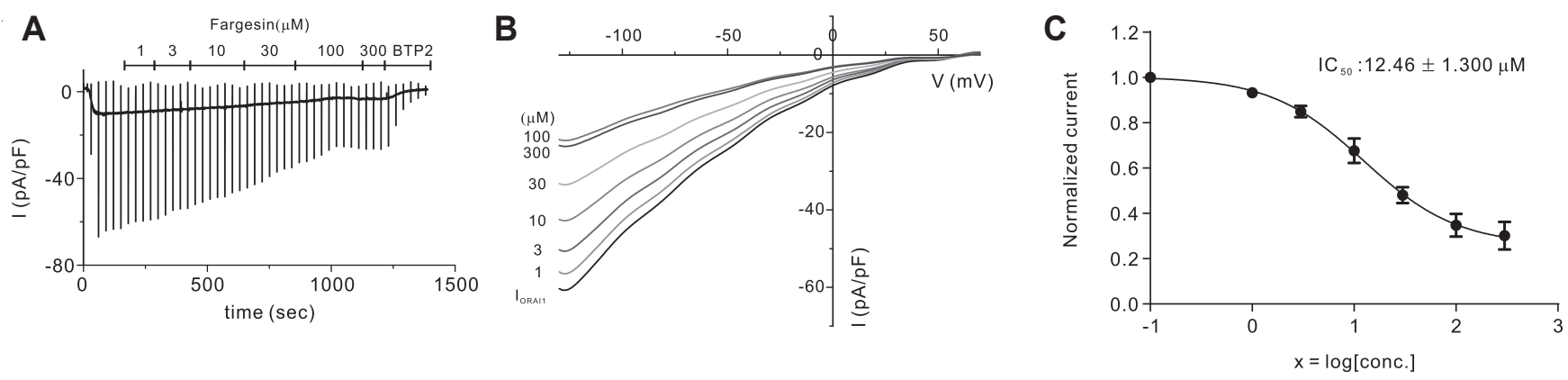

Fig. 2. Effects of fargesin on ORAI1 current $\left(\mathrm{I}_{\mathrm{ORA1}}\right)$. (A) Representative trace chart depicting dose-dependent fargesin inhibition of $\mathrm{I}_{\text {ORAI1 }}$ at $1,3,10$, 30,100 , and $300 \mu \mathrm{M}$. (B) Typical current-voltage (I-V) relationships describing inhibitory proportion of fargesin at a range of concentrations (1-300 $\mu \mathrm{M})$. (C) Concentration dependence of $\mathrm{I}_{\mathrm{ORA1}}$ inhibition by fargesin at $-120 \mathrm{mV}$ and fitted dose-response curves. Values are presented as mean $\pm \mathrm{SEM}$.

A

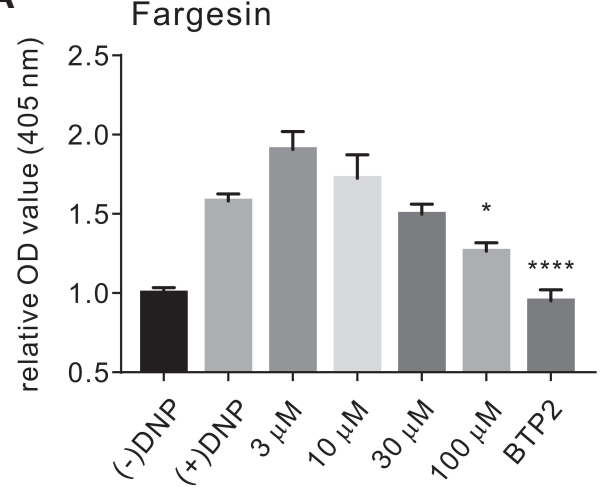

B

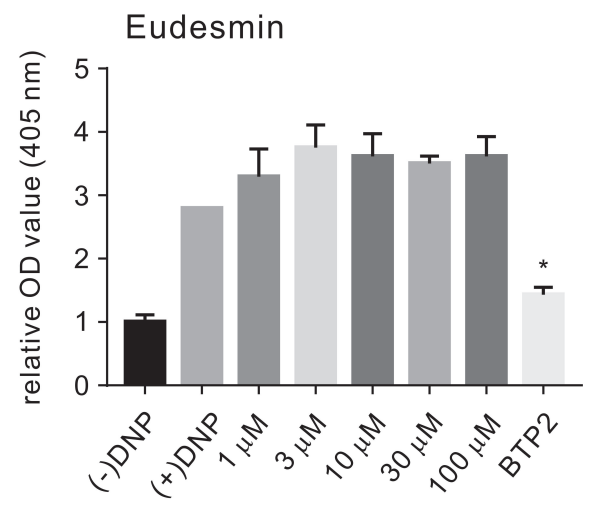

Fig. 3. Inhibitory effects of fargesin and eudesmin on $\boldsymbol{\beta}$-hexosaminidase activity released from RBL-2H3 cells. (A) $\beta$-Hexosaminidase activity in the media after the exposure of IgE-antigen (Ag)-stimulated mast cells to 3, 10, 30, and $100 \mu \mathrm{M}$ fargesin and $10 \mu \mathrm{M}$ BTP2. (B) The release of $\beta$-hexosaminidase in stimulated cells after exposure to $3,10,30$, and $100 \mu \mathrm{M}$ eudesmin and $10 \mu \mathrm{M}$ BTP2. Values are presented as means \pm SEM. ${ }^{*} \mathrm{p}<$ $0.05, * * * * p<0.0001$ vs. control (value of $\beta$-hexosaminidase release in stimulated cells without administration of constituent compounds).

the effects of fargesin and eudesmin on mast cells [31]. Treatment with fargesin or eudesmin suppressed $\beta$-hexosaminidase release compared to that with the positive control (assigned at 100\%). As shown in Fig. 3A, fargesin exhibited a concentration-dependent inhibitory effect on $\beta$-hexosaminidase secretion at 30 and 100 $\mu \mathrm{M}(5.25 \% \pm 6.287 \%$ and $20.11 \% \pm 5.366 \%$, respectively), whereas eudesmin was associated with a value of $129.3 \% \pm 31.49 \%$ at 100 $\mu \mathrm{M}$ (Fig. 3B).

\section{Suppression of primary T cell proliferation}

Prior to testing cell proliferation, we determined the cytotoxicity of the three compounds in a human $\mathrm{T}$ lymphocyte cell line, Jurkat T, using the CCK-8 kit. Treatment with 1, 3, 10, 30, and 100 $\mu \mathrm{M}$ fargesin, eudesmin, or magnolin for $72 \mathrm{~h}$ did not show significant cytotoxic effects in $\mathrm{T}$ cells (Fig. 4A-C). These data were used as a guide for subsequent experiments in this study.

We further examined whether the three $\mathrm{FM}_{\mathrm{EtOH}}$ constituents that showed significant $\mathrm{I}_{\mathrm{SOCE}}$ inhibition could also inhibit $\mathrm{CD} 4^{+} \mathrm{T}$ cell-induced CD3/CD28 co-stimulation. Using flow cytometric analysis of CFSE-labeled T cells, we found that $100 \mu \mathrm{M}$ fargesin, magnolin or eudesmin significantly inhibited $\mathrm{CD}^{+} \mathrm{T}$ cell proliferation by $87.74 \% \pm 1.835 \%, 89.71 \% \pm 0.679 \%$, and $91.11 \% \pm$ $0.667 \%$, respectively (Fig. 4D, E). In summary, results suggested that the three constituents inhibited $\mathrm{I}_{\mathrm{SOCE}}$, $\mathrm{T}$ cell proliferation, and mast cell degranulation, which are implicated in allergic responses.

\section{DISCUSSION}

FM has been successfully applied to treat and relieve several conditions, such as allergic rhinitis, headache, sinusitis, and rheumatoid arthritis. Several FM pharmacological effects, including antiallergic, anti-bacterial, anti-inflammatory, anti-rheumatic, and anti-angiogenic activities, have been previously reported [23,32-36]. Although many reports have indicated the effects of whole FM extracts on intracellular calcium signaling via SOCE, those of its isolated constituents are still under speculation [22]. Previously, we identified five major constituents of $\mathrm{FM}_{\mathrm{EtOH}}$, fargesin, magnolin, eudesmin, vanillic acid, and tiliroside [21]. Hence, 

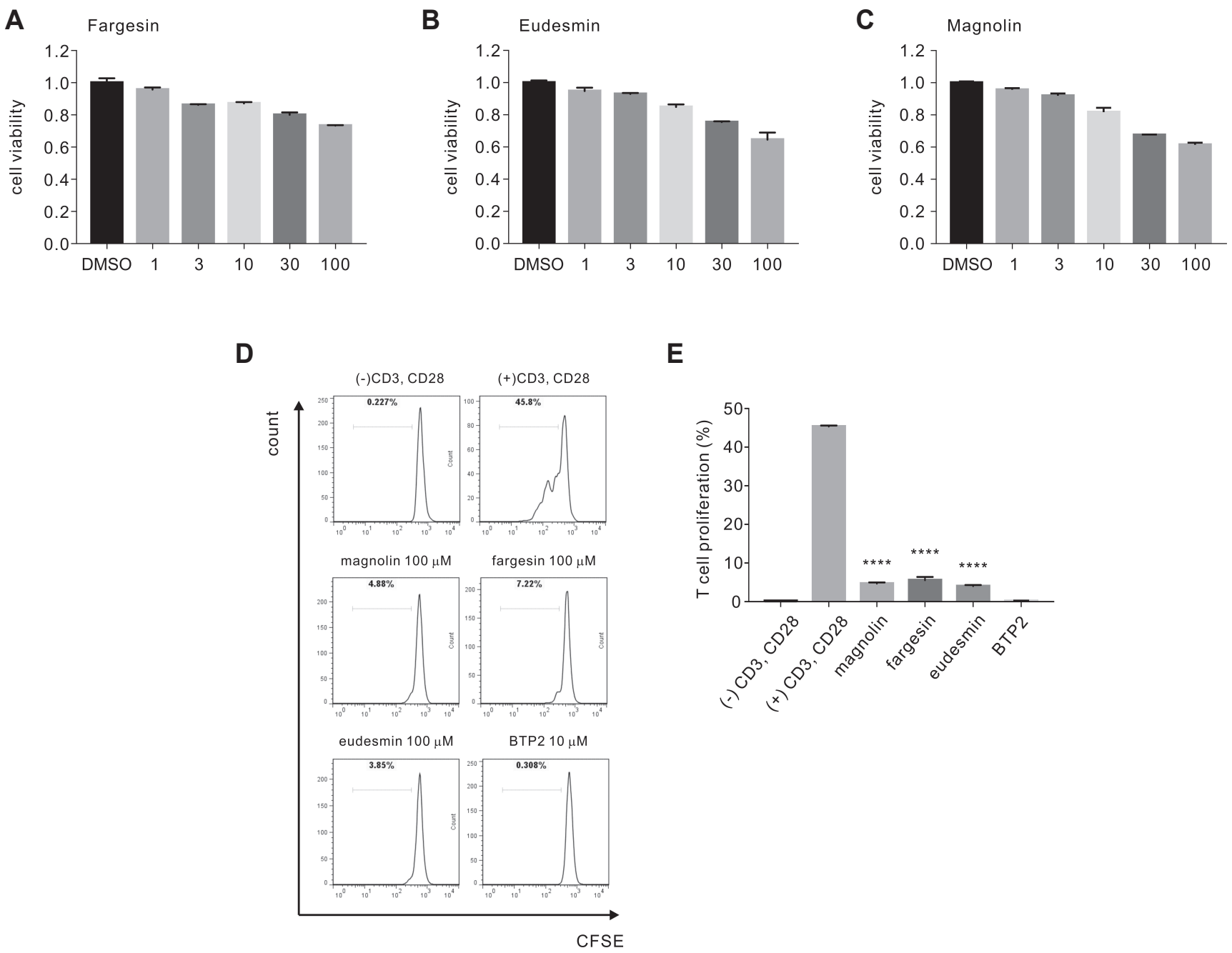

E

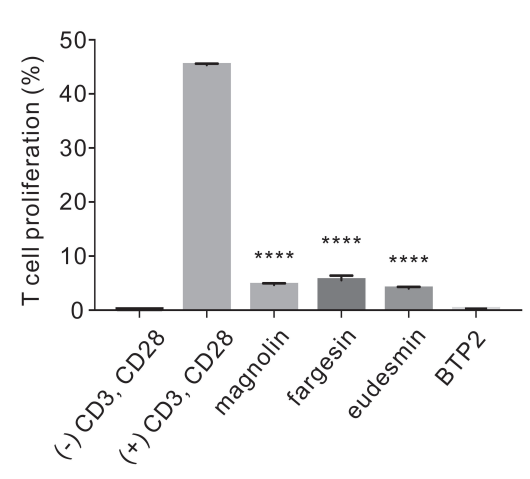

Fig. 4. Inhibitory effects of fargesin, eudesmin, and magnolin on CD3/CD28 co-stimulated human $\mathrm{CD}^{+}{ }^{+}$lymphocyte activation. (A) Fargesin toxicity to Jurkat T cell line after administration of 1, 3, 10, 30, and $100 \mu \mathrm{M}$ based on CCK-8 assay. (B) Eudesmin cytotoxicity to Jurkat T cell at concentrations in (A). (C) Cytotoxic effects of magnolin to Jurkat T cell at concentrations in (A). (D) Representative figure illustrating proliferation of human naïve $\mathrm{CD}^{+} \mathrm{T}$ cells treated with three constituents, and percentage T cell growth inhibition determined by carboxyfluorescein succinimidyl ester (CFSE). Human naïve $\mathrm{CD}^{+} \mathrm{T}$ cells stimulated with antibodies CD3 and CD28 (negative control); CD3/CD28-stimulated cells treated with $10 \mu \mathrm{M}$ BTP2 (positive control). (E) Statistical analysis of percentage $\mathrm{CD}^{+} \mathrm{T}$ cell proliferation with constituent and BTP2 treatments in cells stimulated or not stimulated by $\mathrm{CD} 3 / \mathrm{CD} 28$. ${ }^{* * * *} \mathrm{p}<0.0001$ vs. the control.

in this study, we examined the inhibitory effects of isolated constituents on SOCE through the ORAIl channel, which is essential for activating $\mathrm{T}$ and mast cell degranulation. We hypothesize that the multiple effects of the constituents concomitantly contribute to the pharmacological treatment of allergic diseases by targeting the ORAIl channel.

The results indicate that among the FM constituents, fargesin at $100 \mu \mathrm{M}$ exhibited the most significant effect on the ORAI1 channel (65.58\%), followed by magnolin (29.73\%) and eudesmin and (24.69\%) (Fig. 1A, B). Fargesin is a known bioactive lignan isolated from FM; its multiple effects, such as anti-inflammation, anti-allergy, and other properties, have been reported in several previous studies [23,37-40]. For example, fargesin demonstrated an anti-inflammatory effect in THP-1 melanocytes by inhibiting the calcium-dependent PKC pathway and attenuating chemical-induced intestinal disease [37,38]. Moreover, it relieved atherosclerosis by increasing the efficiency of reverse cholesterol transport and inflammation inhibition [41] and inhibited 5-LOX activity, which partially contributes to allergic diseases [42]. Notwithstanding, there are no reports of its antiallergic effect via the ORAI1 channel. Thus, we used a range of fargesin concentrations on the $\mathrm{I}_{\mathrm{SOCE}}$ in $\mathrm{HEK}_{\mathrm{ORAII}}$ cells. Interestingly, the inhibition was dose-dependent with an $\mathrm{IC}_{50}$ value of $12.46 \pm 1.300 \mu \mathrm{M}$ (Fig. 2A, B).

It has been recently reported that magnolin, a natural ingredient traditionally used to treat allergy, inflammation, nasal congestion, and headache, suppresses the activation of IgE-Aginduced mast cell degranulation in vitro and in vivo via the LynFyn-PLC signaling pathway [31] and reduces $\beta$-hexosaminidase release from bone marrow-derived mast cells [43]. This might be a result of $\mathrm{I}_{\mathrm{SOCE}}$ inhibition by magnolin (Fig. 1B). Therefore, our 
next step was to investigate the inhibitory effects of fargesin and eudesmin on the degranulation response in RBL-2H3 mast cells. Pretreatment with fargesin inhibited $\beta$-hexosaminidase release in a concentration-dependent manner (Fig. 3A). Hence, eudesmin resulted in a significantly lower attenuating effect on degranulation than fargesin (Fig. 3B). These results are consistent with previous studies reporting that the three bisepoxylignans, magnolin, eudesmin, and fargesin, show antiallergic effects at $100 \mu \mathrm{M}$ by inhibiting degranulation and tumour necrosis factor (TNF)- $\alpha$ expression without influencing mast cell viability. Among them, fargesin exerted the most potent antiallergic effect $[43,44]$. Noticeably, the varying levels of inhibitory effects on the ORAI1 channel revealed the differences in the degranulation-inhibition effect between fargesin and eudesmin (Figs. 1B and 3A, B).

In addition to degranulation, we examined the effects of the three constituents (fargesin, eudesmin, and magnolin) on T cell activation. Highly significant inhibition of naïve human $\mathrm{CD} 4^{+} \mathrm{T}$ lymphocyte growth by more than $87 \%$ was observed at $100 \mu \mathrm{M}$ for these three compounds, without significantly affecting cell viability (Fig. 4A). It was previously mentioned that magnolin plays a role in inhibiting cell proliferation and transforming both human breast and lung cancer cells via the ERK1 and ERK2 signaling pathways $[45,46]$. Similarly, eudesmin inhibits TNF- $\alpha$ production in lipopolysaccharide-stimulated RAW 264.7 mouse macrophage cells and concanavalin A-stimulated T cell proliferation in mouse splenocytes [47]. In combination with these reports, our results further highlight the inhibitory effects of the three constituents on $\mathrm{CD}^{+} \mathrm{T}$ cell activation.

In summary, the three $\mathrm{FM}_{\mathrm{EtOH}}$ constituents (fargesin, eudesmin, and magnolin) showed SOCE-inhibitory effects by inhibiting the ORAIl channel that plays a pivotal role in T cell activation and mediator secretion $[15,48]$. As expected, these three compounds exerted significant inhibitory effects on $\mathrm{CD} 4^{+} \mathrm{T}$ cell proliferation and mast cell degranulation. Among them, fargesin showed the most potent effects on SOCE and also effectively inhibited T cells and mast cells. These results indicate the scope for further studies to elucidate a potential role for the three constituents, and especially fargesin, in treating allergic diseases.

\section{ACKNOWLEDGEMENTS}

This study was supported by the Convergence of Conventional Medicine and Traditional Korean Medicine Research \& Development program, funded by the Ministry of Health \& Welfare (Korea) through the Korean Health Industry Development Institute (KHIDI, grant No: HI16C0766) and Basic Science Research Program through the National Research Foundation of Korea (NRF) funded by the Ministry of Education of South Korea (Grant No: 2019R1I1A1A01059077).

\section{CONFLICTS OF INTEREST}

The authors declare no conflicts of interest.

\section{REFERENCES}

1. Junttila IS. Tuning the cytokine responses: an update on interleukin (IL)-4 and IL-13 receptor complexes. Front Immunol. 2018;9:888.

2. Rajan TV. The Gell-Coombs classification of hypersensitivity reactions: a re-interpretation. Trends Immunol. 2003;24:376-379.

3. Galli SJ, Tsai M, Piliponsky AM. The development of allergic inflammation. Nature. 2008;454:445-454.

4. Chassin H, Geering B, Schukur L, Ausländer D, Lang B, Fussenegger M. Sensing and responding to allergic response cytokines through a genetically encoded circuit. Nat Commun. 2017;8:1101.

5. Ozdemir C, Akdis M, Akdis CA. Nature of regulatory T cells in the context of allergic disease. Allergy Asthma Clin Immunol. 2008;4:106-110.

6. Lenon GB, Xue CC, Story DF, Thien FC, McPhee S, Li CG. Inhibition of release of inflammatory mediators in primary and cultured cells by a Chinese herbal medicine formula for allergic rhinitis. Chin Med. 2007;2:2.

7. Izquierdo JH, Bonilla-Abadía F, Cañas CA, Tobón GJ. Calcium, channels, intracellular signaling and autoimmunity. Reumatol Clin. 2014;10:43-47.

8. Ma HT, Beaven MA. Regulation of $\mathrm{Ca}^{2+}$ signaling with particular focus on mast cells. Crit Rev Immunol. 2009;29:155-186.

9. Feske S, Wulff H, Skolnik EY. Ion channels in innate and adaptive immunity. Annu Rev Immunol. 2015;33:291-353.

10. Feske S. CRAC channels and disease - from human CRAC channelopathies and animal models to novel drugs. Cell Calcium. 2019; 80:112-116.

11. Holgate ST, Broide D. New targets for allergic rhinitis--a disease of civilization. Nat Rev Drug Discov. 2003;2:902-914.

12. Bagur R, Hajnóczky G. Intracellular $\mathrm{Ca}^{2+}$ sensing: its role in calcium homeostasis and signaling. Mol Cell. 2017;66:780-788.

13. Yang PC, Jafri MS. $\mathrm{Ca}^{2+}$ signaling in T lymphocytes: the interplay of the endoplasmic reticulum, mitochondria, membrane potential, and CRAC channels on transcription factor activation. Heliyon. 2020;6:e03526.

14. Jafri MS, Keizer J. On the roles of $\mathrm{Ca}^{2+}$ diffusion, $\mathrm{Ca}^{2+}$ buffers, and the endoplasmic reticulum in IP3-induced $\mathrm{Ca}^{2+}$ waves. Biophys J. 1995;69:2139-2153.

15. Vaeth M, Kahlfuss S, Feske S. CRAC channels and calcium signaling in T cell-mediated immunity. Trends Immunol. 2020;41:878901.

16. Feske S. Calcium signals in lymphocyte activation and disease. Cell Commun Signal. 2009;7(Suppl 1):A76.

17. Prakriya M, Lewis RS. Store-operated calcium channels. Physiol Rev. 2015;95:1383-1436.

18. McCarl CA, Picard C, Khalil S, Kawasaki T, Röther J, Papolos A, Kutok J, Hivroz C, Ledeist F, Plogmann K, Ehl S, Notheis G, Albert MH, Belohradsky BH, Kirschner J, Rao A, Fischer A, Feske S. ORAIl deficiency and lack of store-operated $\mathrm{Ca}^{2+}$ entry cause immunodeficiency, myopathy, and ectodermal dysplasia. J Allergy 
Clin Immunol. 2009;124:1311-1318.e7.

19. Yan S, Chen W, Zhang Y, Li J, Chen X. Calcium release-activated calcium modulator 1 as a therapeutic target in allergic skin diseases. Life Sci. 2019;228:152-157.

20. Aki A, Tanaka K, Nagaoka N, Kimura T, Baba D, Onodera Y, Wada T, Maeda H, Nakanishi T, Agatsuma T, Komai T. Anti-ORAI1 antibody DS-2741a, a specific CRAC channel blocker, shows ideal therapeutic profiles for allergic disease via suppression of aberrant T-cell and mast cell activation. FASEB Bioadv. 2020;2:478-488.

21. Kim HJ, Nam YR, Nam JH. Flos Magnoliae inhibits chloride secretion via ANO1 inhibition in Calu-3 cells. Am J Chin Med. 2018;46:1079-1092.

22. Kim HJ, Woo J, Nam YR, Nam JH, Kim WK. Flos Magnoliae and its constituent linoleic acid suppress T lymphocyte activation via store-operated calcium entry. Am J Chin Med. 2019;47:1627-1641.

23. Shen Y, Pang EC, Xue CC, Zhao ZZ, Lin JG, Li CG. Inhibitions of mast cell-derived histamine release by different Flos Magnoliae species in rat peritoneal mast cells. Phytomedicine. 2008;15:808-814.

24. Nguyen TTM, Lee HS, Nguyen TT, Ngo TQM, Jun CD, Min BS, Kim JA. Four new lignans and IL-2 inhibitors from Magnoliae Flos. Chem Pharm Bull (Tokyo). 2017;65:840-847.

25. Shin TY, Kim DK, Chae BS, Lee EJ. Antiallergic action of Magnolia officinalis on immediate hypersensitivity reaction. Arch Pharm Res. 2001;24:249-255.

26. Nam JH, Jung HW, Chin YW, Yang WM, Bae HS, Kim WK. Spirodela polyrhiza extract modulates the activation of atopic dermatitisrelated ion channels, Orail and TRPV3, and inhibits mast cell degranulation. Pharm Biol. 2017;55:1324-1329.

27. Kim HJ, Nam YR, Kim EJ, Nam JH, Kim WK. Spirodela polyrhiza and its chemical constituent vitexin exert anti-allergic effect via ORAI1 channel inhibition. Am J Chin Med. 2018;46:1243-1261.

28. Woo JH, Nam DY, Kim HJ, Hong PTL, Kim WK, Nam JH. Nootkatol prevents ultraviolet radiation-induced photoaging via ORAI1 and TRPV1 inhibition in melanocytes and keratinocytes. Korean $J$ Physiol Pharmacol. 2021;25:87-94.

29. Nam JH, Lee DU. Foeniculum vulgare extract and its constituent, trans-anethole, inhibit UV-induced melanogenesis via ORAI1 channel inhibition. J Dermatol Sci. 2016;84:305-313.

30. Vig M, DeHaven WI, Bird GS, Billingsley JM, Wang H, Rao PE, Hutchings AB, Jouvin MH, Putney JW, Kinet JP. Defective mast cell effector functions in mice lacking the CRACM1 pore subunit of store-operated calcium release-activated calcium channels. Nat Immunol. 2008;9:89-96.

31. Ma P, Che D, Zhao T, Zhang Y, Li C, An H, Zhang T, He H. Magnolin inhibits IgE/Ag-induced allergy in vivo and in vitro. Int Immunopharmacol. 2019;76:105867.

32. Liang Y, Zhang X, Zou J, Shi Y, Wang Y, Tai J, Yang Y, Zhou X, Guo D, Wang J, Cheng J, Yang M. Pharmacology mechanism of Flos magnoliae and Centipeda minima for treating allergic rhinitis based on pharmacology network. Drug Dev Ind Pharm. 2019;45:1547-1555.

33. Jung YS, Weon JB, Yang WS, Ryu G, Ma CJ. Neuroprotective effects of Magnoliae Flos extract in mouse hippocampal neuronal cells. Sci Rep. 2018;8:9693.

34. Kobayashi S, Kobayashi H, Matsuno H, Kimura I, Kimura M. Inhibitory effects of anti-rheumatic drugs containing magnosalin, a compound from 'Shin-i' (Flos magnoliae), on the proliferation of sy- novial cells in rheumatoid arthritis models. Immunopharmacology. 1998;39:139-147.

35. Kim GC, Lee SG, Park BS, Kim JY, Song YS, Kim JM, Yoo KS, Huh GY, Jeong MH, Lim YJ, Kim HM, Yoo YH. Magnoliae flos induces apoptosis of RBL-2H3 cells via mitochondria and caspase. Int Arch Allergy Immunol. 2003;131:101-110.

36. Galli SJ, Gaudenzio N, Tsai M. Mast cells in inflammation and disease: recent progress and ongoing concerns. Annu Rev Immunol. 2020;38:49-77.

37. Pham TH, Kim MS, Le MQ, Song YS, Bak Y, Ryu HW, Oh SR, Yoon DY. Fargesin exerts anti-inflammatory effects in THP-1 monocytes by suppressing PKC-dependent AP-1 and NF-kB signaling. Phytomedicine. 2017;24:96-103.

38. Yue B, Ren YJ, Zhang JJ, Luo XP, Yu ZL, Ren GY, Sun AN, Deng C, Wang ZT, Dou W. Anti-inflammatory effects of fargesin on chemically induced inflammatory bowel disease in mice. Molecules. 2018;23:1380.

39. Wang X, Cheng Y, Xue H, Yue Y, Zhang W, Li X. Fargesin as a potential $\beta_{1}$ adrenergic receptor antagonist protects the hearts against ischemia/reperfusion injury in rats via attenuating oxidative stress and apoptosis. Fitoterapia. 2015;105:16-25.

40. Fu T, Chai B, Shi Y, Dang Y, Ye X. Fargesin inhibits melanin synthesis in murine malignant and immortalized melanocytes by regulating PKA/CREB and P38/MAPK signaling pathways. J Dermatol Sci. 2019;94:213-219.

41. Wang G, Gao JH, He LH, Yu XH, Zhao ZW, Zou J, Wen FJ, Zhou L, Wan XJ, Tang CK. Fargesin alleviates atherosclerosis by promoting reverse cholesterol transport and reducing inflammatory response. Biochim Biophys Acta Mol Cell Biol Lipids. 2020;1865:158633.

42. Lim H, Son KH, Bae KH, Hung TM, Kim YS, Kim HP. 5-lipoxygenase-inhibitory constituents from Schizandra fructus and Magnolia flos. Phytother Res. 2009;23:1489-1492.

43. Zhang X, Qian F, Tan JJ, Guo FJ, Kulka M, Xu JW, Li YM. Bioassayguided isolation of bisepoxylignans from the flower buds of Magnolia biondii Pamp and their antiallergic effects. RSC Advances. 2017;7:34236-34243.

44. Lin Y, Xu J, Jia Q, Sun W, Fu J, Lv Y, Han S. Cell membrane chromatography coupled online with LC-MS to screen anti-anaphylactoid components from Magnolia biondii Pamp. targeting on Mas-related G protein-coupled receptor X2. J Sep Sci. 2020;43:2571-2578.

45. Lee CJ, Lee MH, Yoo SM, Choi KI, Song JH, Jang JH, Oh SR, Ryu HW, Lee HS, Surh YJ, Cho YY. Magnolin inhibits cell migration and invasion by targeting the ERKs/RSK2 signaling pathway. BMC Cancer. 2015;15:576.

46. Wang J, Zhang S, Huang K, Shi L, Zhang Q. Magnolin inhibits proliferation and invasion of breast cancer MDA-MB-231 cells by targeting the ERK1/2 signaling pathway. Chem Pharm Bull (Tokyo). 2020;68:421-427.

47. Cho JY, Yoo ES, Baik KU, Park MH. Eudesmin inhibits tumor necrosis factor-alpha production and T cell proliferation. Arch Pharm Res. 1999;22:348-353.

48. Lioudyno MI, Kozak JA, Penna A, Safrina O, Zhang SL, Sen D, Roos J, Stauderman KA, Cahalan MD. Orail and STIM1 move to the immunological synapse and are up-regulated during T cell activation. Proc Natl Acad Sci U S A. 2008;105:2011-2016. 